\title{
Use of proton pump inhibitors is associated with a higher risk of pneumonia in cirrhotic patients: a systematic review and meta-analysis
}

\author{
Wasit Wongtrakula ${ }^{\text {, Nipith Charoenngnam }}{ }^{\mathrm{b}}$, Patompong Ungprasertc
}

Siriraj Hospital, Mahidol University, Bangkok, Thailand

Abstract

Background Proton pump inhibitors (PPIs) are commonly prescribed for cirrhotic patients. However, the use of PPIs in these patients may increase the risk of bacterial infection. The current study aimed to investigate the risk of developing pneumonia among cirrhotic patients exposed to PPIs. Methods A literature search was independently conducted by 2 investigators using the MEDLINE
and EMBASE databases up to September 2019. To be eligible, a study had to be an observational
(cohort, case-control or cross-sectional) study that included one group of cirrhotic patients with
PPI use and another group of cirrhotic patients without PPI use. Effect estimates of the association
between PPI use and pneumonia had to be reported. Point estimates and standard errors from each
eligible study were combined together using the generic inverse variance method of DerSimonian
and Laird.

Results Of 1947 articles identified from the 2 databases, 3 cohort and 5 cross-sectional studies with 40,295 participants met the eligibility criteria and were included in the meta-analysis. The pooled analysis found that cirrhotic patients with a history of PPI use had a significantly higher risk of developing pneumonia than those without PPI use, with a pooled risk ratio of 1.36 (95\% confidence interval $\left.1.00-1.85 ; I^{2} 47 \%\right)$.

Conclusion A significantly increased risk of pneumonia among cirrhotic patients exposed to PPIs was demonstrated in this study.

Keywords Pneumonia, proton pump inhibitors, cirrhosis, epidemiology, meta-analysis

Ann Gastroenterol 2020; 33 (3): 1-11

\section{Introduction}

Cirrhosis accounts for approximately 1 million deaths annually [1]. Common complications of liver cirrhosis include variceal bleeding, ascites, hepatic encephalopathy, hepatorenal syndrome, and spontaneous bacterial peritonitis

${ }^{\mathrm{a} F a c u l t y ~ o f ~ M e d i c i n e ~(W a s i t ~ W o n g t r a k u l) ; ~}{ }^{\mathrm{b}}$ Department of Internal Medicine, Faculty of Medicine (Nipith Charoenngnam); ${ }^{\mathrm{c} C l i n i c a l}$ Epidemiology Unit, Department of Research and Development, Faculty of Medicine (Patompong Ungprasert), Siriraj Hospital, Mahidol University, Bangkok, Thailand

Conflict of Interest: None

Correspondence to: Patompong Ungprasert, Clinical Epidemiology Unit, $3^{\text {rd }}$ floor, SIMR building, Siriraj Hospital, 10700, Bangkok, Thailand, e-mail: P.Ungprasert@gmail.com

Received 13 January 2020; accepted 4 March 2020; published online 13 April 2020

DOI: https://doi.org/10.20524/aog.2020.0483
(SBP) [2]. In addition, cirrhosis is associated with an increased risk and poorer prognosis of several other types of bacterial infection, such as bacteremia, enterocolitis, skin and soft tissue infection, urinary tract infection, meningitis, and infective endocarditis [3]. Cirrhosis-associated immune dysfunction is thought to be the key player in this increased risk [4].

Proton pump inhibitors (PPI) are commonly prescribed for cirrhotic patients, although studies have shown that over half of PPI use was without valid indications [5], which may lead to an unnecessary increased incidence of several complications, such as hepatic encephalopathy, Clostridium difficile infection and SBP [6]. The possible explanation for the increased likelihood of developing SBP among PPI users is that acid suppression facilitates bacterial overgrowth and translocation [7-9]. The use of PPI may also lead to an increased risk of other types of organspecific bacterial infection. In fact, studies have suggested an increased risk of bacterial pneumonia among cirrhotic patients who use PPIs, although the results are inconsistent [10-17]. The current study aimed to further investigate this risk by identifying all available studies and summarizing their results together. 


\section{Materials and methods}

\section{Information sources and search strategy}

A systematic literature review based on the EMBASE and MEDLINE databases was performed independently by 2 investigators (WW and NC) from inception to September 2019 to identify all published studies that examined the risk or association between pneumonia and PPI use in cirrhotic patients. The search strategy, which included the terms "proton pump inhibitors" and "cirrhosis", is available as Supplementary Table 1. In addition, we manually reviewed the references of the eligible studies to identify any additional potential articles. This study was performed according to the Preferred Reporting Items for Systematic Reviews and Meta-Analyses statement (Supplementary Table 2).

\section{Selection criteria}

To be eligible, a study had to be an observational study (cohort, case-control or cross-sectional study) that included one group of cirrhotic patients with PPI use and another group of cirrhotic patients without PPI use.

- Eligible cohort studies started with recruitment of cirrhotic patients who used and did not use PPIs and followed them for incident pneumonia. Relative risk (RR), incidence rate ratio (IRR), hazard risk ratio (HR) or standardized incidence ratio (SIR) with associated 95\% confidence interval (CI) comparing the incidence of pneumonia between cirrhotic patients with and without PPI use had to be provided.

- Eligible case-control studies started with recruitment of cases of cirrhotic patients with pneumonia and controls who were cirrhotic patients without pneumonia and explored their history of PPI use. Odds ratio (OR) with associated 95\% CI comparing the prevalence of PPI use between cases versus controls had to be reported.

- Eligible cross-sectional studies recruited cirrhotic patients and explored the history of PPI use and pneumonia at the same time. OR with associated $95 \% \mathrm{CI}$ of this association had to be reported. No language limitation was applied during the systematic review.

\section{Data extraction}

We used a standardized data collection form to extract the following information: last name of the first author, country where the study was conducted, study design, year of publication, number of participants, recruitment of participants, how the diagnosis of pneumonia and ascertainment of PPI use were justified, follow-up period and duration (for cohort studies), baseline characteristics of participants, confounders adjusted in multivariate analysis and adjusted effect estimates with corresponding 95\%CI. We appraised the quality of the included cohort and case-control studies using the Newcastle-Ottawa quality assessment scale [18]. The modified version of this scale was used for cross-sectional studies.

\section{Statistical analysis}

We utilized Review Manager 5.3 software from the Cochrane Collaboration (London, United Kingdom) to analyze all data. Point estimates and standard errors from each study were pooled together using the generic inverse variance method of DerSimonian and Laird, which assigns the weight of the study in reverse to its variance [19]. A random-effect model, rather than a fixed-effect model, was used, as the assumption of the fixed-effect model that every study should give rise to the same result is not justified under almost all circumstances, especially in a meta-analysis of observational studies. Statistical heterogeneity was assessed by Cochran's Q test, complimented by the $I^{2}$ statistic. This $I^{2}$ statistic quantifies the proportion of total variation across studies due to heterogeneity rather than chance. A value of $I^{2}$ of $0-25 \%$ represents insignificant heterogeneity, 26-50\% represents low heterogeneity, 51$75 \%$ represents moderate heterogeneity, and $76 \%$ or higher represents high heterogeneity [20]. The presence of publication bias was assessed by visualization of a funnel plot along with Egger's regression test. Egger's regression test was conducted using Comprehensive Meta-analysis 3.0 software (Englewood, New Jersey, United States).

\section{Results}

A total of 1947 articles (276 from MEDLINE and 1671 from EMBASE) were identified, from which 237 duplicated articles were removed, leaving 1710 articles for title and abstract review. At this stage of review, 1675 articles were excluded because they were clearly ineligible based on study design and type of article. Therefore, 35 full-length articles were thoroughly reviewed, and 27 articles were further excluded as they did not report the outcome of interest. Finally, 3 cohort and 5 cross-sectional studies with a total of 40,295 participants met the eligibility criteria and were included in the metaanalysis [10-17]. Two of the 3 included cohort studies were published as conference abstracts $[10,14]$. No eligible casecontrol study was identified. Fig. 1 summarizes the literature review and study selection process. Tables 1 and 2 describe the characteristics and Newcastle-Ottawa assessment scales of the included cross-sectional and cohort studies, respectively.

\section{Risk of pneumonia among cirrhotic patients exposed to PPI}

Cirrhotic patients with a history of PPI use had a significantly higher risk of developing pneumonia than those without PPI use, with a pooled RR of 1.36 (95\%CI 1.00-1.85). The statistical heterogeneity was low, with an $I^{2}$ of $47 \%$.

Subgroup analysis by study design showed an increased risk in both cohort and cross-sectional study subgroups, although the number of included studies was not large enough to demonstrate statistical significance (pooled RR 1.26, 95\% CI 0.80-1.99, I $I^{2}$ 57\%, for cohort studies; pooled RR 1.49, 95\%CI 


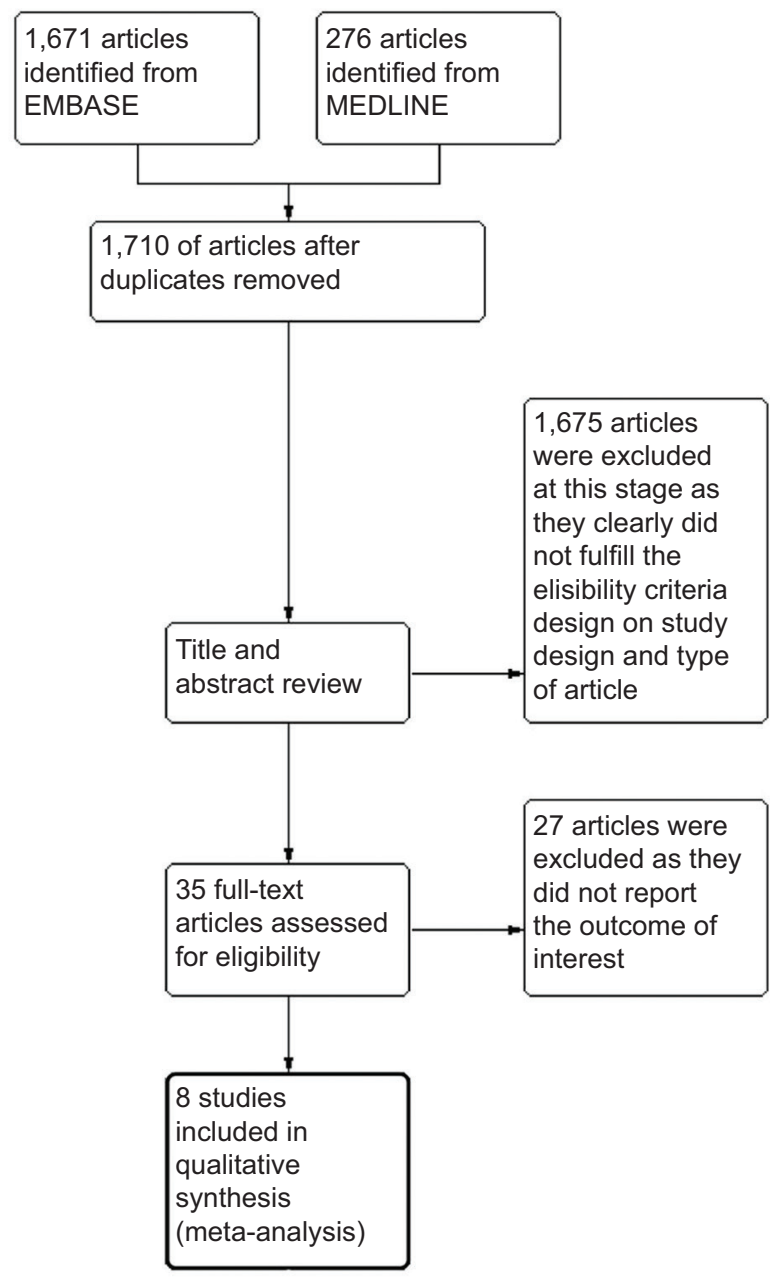

Figure 1 Literature review and study selection process
0.98-2.26, $I^{2} 22 \%$, for cross-sectional studies). Fig. 2 shows the forest plot of this meta-analysis.

\section{Evaluation for publication bias}

The funnel plot of this meta-analysis (Fig. 3) was fairly asymmetric. In addition, publication bias was detected by Egger's regression test with a P-value of 0.003 .

\section{Discussion}

The current study is the first systematic review and metaanalysis to comprehensively identify all observational studies that evaluated the risk of pneumonia associated with PPI use among patients with cirrhosis. The pooled analysis from over 40,000 patients found an approximately 1.4-fold higher risk of pneumonia among cirrhotic patients with exposure to PPI. An increased risk of pneumonia among PPI-users has also been observed in the general population, as demonstrated by a recent meta-analysis [21]. In fact, the magnitude of the increased risk in the general population studies, 1.49-fold, is comparable to this study. The mechanisms accounting for the increased risk of pneumonia have not been clearly elucidated, but there are several possible explanations.

The first possible mechanism is that PPI use decreases gastric acidity, thus facilitating the proliferation of Streptococcus spp. and Lactobacillus spp. in the stomach [22]. Aspiration of colonized gastric fluid may have a higher tendency to cause pneumonia than aspiration of relatively sterile gastric fluid [23]. In fact, a study by Viasus et al identified an increased proportion of Streptococcus pneumoniae as a causative

Table 1 Main characteristics of the cross-sectional studies included in this meta-analysis

\begin{tabular}{|c|c|c|c|}
\hline Characteristics & Merli et al [16] & Terg et al [17] & Elzouki et al [12] \\
\hline Country & Italy & Argentina & Qatar \\
\hline Study design & Cross-sectional study & Cross-sectional study & Cross-sectional study \\
\hline Year of publication & 2015 & 2015 & 2018 \\
\hline $\begin{array}{l}\text { Number of } \\
\text { participants }\end{array}$ & $\begin{array}{l}167 \text { ( } 127 \text { PPI users and } 40 \text { non- } \\
\text { users) }\end{array}$ & 521 (226 PPI users and 295 non-users) & $\begin{array}{l}333 \text { (171 PPI users and } 162 \text { non- } \\
\text { users) }\end{array}$ \\
\hline \multirow[t]{2}{*}{$\begin{array}{l}\text { Recruitment of } \\
\text { participants }\end{array}$} & $\begin{array}{l}\text { Participants were consecutive } \\
\text { cirrhotic patients admitted to the } \\
\text { Sapienza University of Rome, Italy } \\
\text { from October } 2008 \text { to January } 2013\end{array}$ & $\begin{array}{l}\text { Participants were consecutive cirrhotic } \\
\text { patients admitted to one of } 23 \text { hospitals } \\
\text { in Argentina from March } 2011 \text { to April } \\
2012\end{array}$ & $\begin{array}{l}\text { Participants were consecutive } \\
\text { cirrhotic patients admitted to Hamad } \\
\text { General Hospital from } 2007 \text { to } 2012\end{array}$ \\
\hline & $\begin{array}{l}\text { Patients with HIV infection, } \\
\text { high-dose corticosteroid } \\
\text { treatment, immunosuppressive } \\
\text { therapy, hepatocellular carcinoma } \\
\text { or systemic antibiotic therapy in } \\
\text { the last } 4 \text { weeks were excluded }\end{array}$ & $\begin{array}{l}\text { Patients with active gastroduodenal } \\
\text { bleeding, antibiotic treatment in the } \\
\text { previous } 2 \text { weeks, including quinolone } \\
\text { or rifaximin prophylaxis, HIV infection } \\
\text { and immunosuppressive therapy were } \\
\text { excluded }\end{array}$ & $\begin{array}{l}\text { Patients with active gastroduodenal } \\
\text { bleeding, disseminated } \\
\text { malignancies, antibiotic treatment } \\
\text { in the previous } 2 \text { weeks, } \\
\text { immunosuppressive therapy prior to } \\
\text { hospitalization were excluded }\end{array}$ \\
\hline $\begin{array}{l}\text { Ascertainment of } \\
\text { PPI use }\end{array}$ & $\begin{array}{l}\text { History of PPI use was } \\
\text { ascertained from direct interview } \\
\text { by the investigators }\end{array}$ & $\begin{array}{l}\text { History of PPI use was ascertained from } \\
\text { direct interview by the investigators }\end{array}$ & $\begin{array}{l}\text { History of PPI use was ascertained } \\
\text { from medical record review }\end{array}$ \\
\hline
\end{tabular}


Table 1 (Continued)

\begin{tabular}{|c|c|c|c|}
\hline Characteristics & Merli et al [16] & Terg et al [17] & Elzouki et al [12] \\
\hline $\begin{array}{l}\text { Definition of PPI } \\
\text { users and non-users }\end{array}$ & $\begin{array}{l}\text { PPI users were patients who had } \\
\text { used PPI daily for at least } 4 \text { weeks } \\
\text { prior to admission } \\
\text { Those who did not meet the } \\
\text { criteria were considered non-users }\end{array}$ & $\begin{array}{l}\text { PPI users were patients with any PPI use } \\
\text { in the } 3 \text { months prior to hospitalization }\end{array}$ & $\begin{array}{l}\text { PPI users were patients with any } \\
\text { PPI use in the } 3 \text { months prior to } \\
\text { hospitalization }\end{array}$ \\
\hline $\begin{array}{l}\text { Diagnosis of } \\
\text { pneumonia }\end{array}$ & $\begin{array}{l}\text { Diagnosis of pneumonia was } \\
\text { made based on standard criteria. } \\
\text { Pneumonia was actively sought } \\
\text { out throughout the hospital stay }\end{array}$ & $\begin{array}{l}\text { Diagnosis of pneumonia was made based } \\
\text { on standard criteria }\end{array}$ & $\begin{array}{l}\text { New pulmonary infiltration in the } \\
\text { presence of a) at least } 1 \text { respiratory } \\
\text { symptom (cough, sputum } \\
\text { production, dyspnea, pleuritic chest } \\
\text { pain) with b) at least } 1 \text { finding on } \\
\text { auscultation (rales or crepitation) or } \\
\text { signs of infection }\end{array}$ \\
\hline MELD score & $\begin{array}{l}\text { PPI users: } 12.5 \\
\text { Non-users: } 13.1\end{array}$ & $\begin{array}{l}\text { PPI users: } 19.2 \\
\text { Non-users: } 19.0\end{array}$ & $\begin{array}{l}\text { PPI users: N/A } \\
\text { Non-users: N/A }\end{array}$ \\
\hline Child-Pugh score & $\begin{array}{l}\text { PPI users: } 7.7 \\
\text { Non-users: } 8.2\end{array}$ & $\begin{array}{l}\text { PPI users: } 11.2 \\
\text { Non-users: } 10.5\end{array}$ & $\begin{array}{l}\text { PPI users } \\
\text { Child-Pugh A: } 37.4 \% \\
\text { Child-Pugh B: } 38 \% \\
\text { Child-Pugh C: } 24.6 \% \\
\text { Non-users } \\
\text { Child-Pugh A: } 43.8 \% \\
\text { Child-Pugh B: } 34.6 \% \\
\text { Child-Pugh C: } 21.6 \%\end{array}$ \\
\hline Percentage of male & $\begin{array}{l}\text { PPI users: } 29.4 \\
\text { Non-users: } 69.5\end{array}$ & $\begin{array}{l}\text { PPI users: } 63.6 \% \\
\text { Non-users: } 75.3 \%\end{array}$ & $\begin{array}{l}\text { PPI users: } 73.7 \% \\
\text { Non-users: } 82.7 \%\end{array}$ \\
\hline Comorbidities & $\begin{array}{l}\text { PPI users } \\
\text { Diabetes mellitus: } 32.7 \% \\
\text { Renal failure: } 11.5 \% \\
\text { Non-users } \\
\text { Diabetes mellitus: } 27.5 \% \\
\text { Renal failure: } 5.3 \%\end{array}$ & $\begin{array}{l}\text { PPI users } \\
\text { Active alcohol consumption: } 53.7 \% \\
\text { Non-users } \\
\text { Active alcohol consumption: } 51.1 \%\end{array}$ & $\begin{array}{l}\text { PPI users } \\
\text { Smoker: } 32.2 \% \\
\text { Diabetes mellitus: } 55 \% \\
\text { Hypertension: } 38.6 \% \\
\text { Chronic kidney disease: } 5.3 \% \\
\text { Non-users } \\
\text { Smoker: } 29.6 \% \\
\text { Diabetes mellitus: } 36.4 \% \\
\text { Hypertension: } 21.6 \% \\
\text { Chronic kidney disease: } 1.9 \%\end{array}$ \\
\hline $\begin{array}{l}\text { Confounder adjusted } \\
\text { in multivariate } \\
\text { analysis }\end{array}$ & None & None & None \\
\hline $\begin{array}{l}\text { Quality assessment } \\
\text { (Newcastle-Ottawa } \\
\text { scale) }\end{array}$ & $\begin{array}{l}\text { Selection: } 4 \\
\text { Comparability: } 0 \\
\text { Outcome: } 3\end{array}$ & $\begin{array}{l}\text { Selection: } 5 \\
\text { Comparability: } 0 \\
\text { Outcome: } 3\end{array}$ & $\begin{array}{l}\text { Selection: } 4 \\
\text { Comparability: } 0 \\
\text { Outcome: } 3\end{array}$ \\
\hline
\end{tabular}

\begin{tabular}{|c|c|c|}
\hline Characteristics & Joao et al [14] & Fasullo et al [13] \\
\hline Country & Portugal & United States \\
\hline Study design & Cross-sectional study & Cross-sectional study \\
\hline Year of publication & 2019 & 2019 \\
\hline Number of participants & 396 (183 PPI users and 213 non-users) & 103 (75 PPI users and 28 non-users) \\
\hline Recruitment of participants & $\begin{array}{l}\text { Participants were consecutive cirrhotic } \\
\text { patients admitted to the study hospital } \\
\text { from January } 2015 \text { to June } 2018\end{array}$ & $\begin{array}{l}\text { Participants were consecutive cirrhotic patients admitted with } \\
\text { hepatic encephalopathy to the University of Massachusetts } \\
\text { Memorial Medical Center from January } 2013 \text { to December } 2016 \\
\text { Patients with pregnancy and HIV were excluded }\end{array}$ \\
\hline MELD score & $\begin{array}{l}\text { MELD-Na score } \\
\text { PPI users: } 18 \\
\text { Non-users: } 17\end{array}$ & $\begin{array}{l}\text { PPI users: } 19.7 \\
\text { Non-users: } 20.3\end{array}$ \\
\hline
\end{tabular}

(Contd...) 
Table 1 (Continued)

\begin{tabular}{lll}
\hline Child-Pugh score & $\begin{array}{l}\text { PPI users } \\
\text { Child-Pugh B: } 54.6 \% \\
\text { Non-users } \\
\text { Child-Pugh B: } 45.5 \%\end{array}$ & N/A \\
\hline $\begin{array}{l}\text { Average age of participants } \\
\text { (years) }\end{array}$ & $\begin{array}{l}\text { PPI users: } 69.0 \\
\text { Non-users: } 66.0\end{array}$ & $\begin{array}{l}\text { PPI users: } 59.6 \\
\text { Non-users: } 55.3\end{array}$ \\
\hline Percentage of male & PPI users: 69.4 & PPI users: $63.5 \%$ \\
Non-users: 75.6 & Non-users: $47.2 \%$
\end{tabular}

Table 2 Main characteristics of the cohort studies included in the meta-analysis

\begin{tabular}{|c|c|c|c|}
\hline Characteristics & Bang et al [10] & Lazaro-Pacheco et al [15] & Dam et al [11] \\
\hline Country & Denmark & Mexico & $\begin{array}{l}\text { Canada, Denmark, France, } \\
\text { Germany, Italy and Spain }\end{array}$ \\
\hline Study design & Retrospective cohort & Retrospective cohort & Retrospective cohort \\
\hline Year of publication & 2017 & 2018 & 2019 \\
\hline $\begin{array}{l}\text { Total number of } \\
\text { participants }\end{array}$ & $\begin{array}{l}\text { PPI users: } 18,732 \\
\text { Non-users: } 18,732\end{array}$ & $\begin{array}{l}\text { PPI users: } 69 \\
\text { Non-users: } 44\end{array}$ & $\begin{array}{l}\text { PPI users at inclusion: } 524 \\
\text { Non-users at inclusion: } 674\end{array}$ \\
\hline $\begin{array}{l}\text { Recruitment of } \\
\text { participants }\end{array}$ & $\begin{array}{l}\text { Cirrhotic patients who were } \\
\text { PPI users and non-users were } \\
\text { identified from the Danish } \\
\text { Registry from } 1995 \text { to } 2014 \\
\text { PPI users and non-users were } \\
\text { matched in a } 1: 1 \text { ratio using } \\
\text { propensity score }\end{array}$ & $\begin{array}{l}\text { Cirrhotic patients who were PPI } \\
\text { users and non-users were identified } \\
\text { from the database of the Liver Clinic } \\
\text { in a tertiary health-care center in } \\
\text { Mexico } \\
\text { Patients with diagnosis of } \\
\text { hepatocellular carcinoma, } \\
\text { concomitant comorbidities such } \\
\text { as diabetes, chronic renal disease, } \\
\text { with active alcohol intake during } \\
\text { follow-up period and human } \\
\text { immunodeficiency virus infection } \\
\text { were excluded }\end{array}$ & $\begin{array}{l}\text { Cirrhotic patients who were } \\
\text { PPI users and non-users were } \\
\text { identified from the databases of } \\
\text { the } 3 \text { satavaptan randomized- } \\
\text { controlled trials conducted in } \\
\text { 2006-2008. These trials included } \\
\text { only patients with ascites } \\
\text { Patients with a functioning trans- } \\
\text { jugular intrahepatic portosystemic } \\
\text { shunt, hepatocellular carcinoma, } \\
\text { variceal bleeding or spontaneous } \\
\text { bacterial peritonitis in the } 10 \\
\text { days before randomization were } \\
\text { excluded }\end{array}$ \\
\hline Ascertainment of PPI use & $\begin{array}{l}\text { History of PPI use was } \\
\text { ascertained from pharmacy } \\
\text { database of the registry }\end{array}$ & $\begin{array}{l}\text { History of PPI use was ascertained } \\
\text { from medical records of the clinic }\end{array}$ & $\begin{array}{l}\text { History of PPI use was ascertained } \\
\text { from the databases of the trials } \\
\text { The history was prospectively } \\
\text { recorded by investigators of the } \\
\text { trials in every visit }\end{array}$ \\
\hline
\end{tabular}

(Contd...) 
Table 2 (Continued)

\begin{tabular}{|c|c|c|c|}
\hline $\begin{array}{l}\text { Definition of PPI user and } \\
\text { non-user }\end{array}$ & $\begin{array}{l}\text { PPI users were defined as patients } \\
\text { with at least } 2 \text { prescriptions for } \\
\text { PPI in the database }\end{array}$ & $\begin{array}{l}\text { PPI users were defined as patients } \\
\text { who had history of taking PPI, at } \\
\text { least for } 1 \text { year, for the last year, and } \\
\text { at least } 3 \text { times per week, and in a } \\
\text { minimum dose of } 20 \mathrm{mg} / \text { day }\end{array}$ & $\begin{array}{l}\text { A patient contributed follow-up } \\
\text { time to the "PPI user" group when } \\
\text { he/she was using PPI and to the } \\
\text { "PPI nonuser group" when he/she } \\
\text { was not }\end{array}$ \\
\hline & $\begin{array}{l}\text { PPI non-users were defined as } \\
\text { patients who had no prescription } \\
\text { for PPI in the database }\end{array}$ & $\begin{array}{l}\text { PPI non-users were defined as } \\
\text { patients who had no history of } \\
\text { taking PPI }\end{array}$ & \\
\hline Diagnosis of pneumonia & $\begin{array}{l}\text { Presence of ICD- } 10 \text { codes for } \\
\text { bacterial pneumonia (J15, J17 and } \\
\text { J18) in the registry }\end{array}$ & $\begin{array}{l}\text { Diagnosis of bacterial pneumonia } \\
\text { was ascertained from medical } \\
\text { records of clinic plus confirmation } \\
\text { by bacterial culture }\end{array}$ & $\begin{array}{l}\text { Diagnosis of bacterial pneumonia } \\
\text { was ascertained from the databases } \\
\text { of the trails } \\
\text { The diagnosis was made by } \\
\text { attending clinicians and was } \\
\text { prospectively recorded by } \\
\text { investigators of the trials in every } \\
\text { visit }\end{array}$ \\
\hline Follow up & $\mathrm{N} / \mathrm{A}$ & $\begin{array}{l}\text { Medical records were reviewed for } \\
3 \text { years after index date (PPI users: } \\
\text { date start taking PPI; Non users: date } \\
\text { of diagnosis of cirrhosis) }\end{array}$ & $\begin{array}{l}\text { Patients were followed up every } 4 \\
\text { weeks until completion of study } \\
\text { ( } 52 \text { weeks), premature satavaptan } \\
\text { treatment cessation or death. }\end{array}$ \\
\hline Follow-up duration (years) & N/A & 3.0 & 1.0 \\
\hline MELD score & N/A & $\mathrm{N} / \mathrm{A}$ & $\begin{array}{l}\text { PPI users: } 15 \\
\text { Non-users: } 14\end{array}$ \\
\hline Child-Pugh score & N/A & $\begin{array}{l}\text { PPI users } \\
\text { Child-Pugh A: } 59.4 \% \\
\text { Child-Pugh B: } 37.7 \% \\
\text { Child-Pugh C: } 31.9 \% \\
\text { Non-users } \\
\text { Child-Pugh A: } 56.8 \% \\
\text { Child-Pugh B: } 31.8 \% \\
\text { Child-Pugh C: } 11.4 \%\end{array}$ & N/A \\
\hline $\begin{array}{l}\text { Average age of participants } \\
\text { (years }\end{array}$ & Overall: 55.0 & $\begin{array}{l}\text { PPI users: } 62.6 \\
\text { Non-users: } 61.7\end{array}$ & $\begin{array}{l}\text { PPI users at inclusion: } 58.0 \\
\text { Non-users at inclusion: } 57.0\end{array}$ \\
\hline Percentage of male & Overall: $70.0 \%$ & $\begin{array}{l}\text { PPI users: } 40.9 \% \\
\text { Non-users: } 43.5 \%\end{array}$ & $\begin{array}{l}\text { PPI users at inclusion: } 69.7 \% \\
\text { Non-users at inclusion: } 69.6 \%\end{array}$ \\
\hline $\begin{array}{l}\text { Variables adjusted in } \\
\text { multivariate analysis }\end{array}$ & None & None & $\begin{array}{l}\text { Age, sex, cirrhosis etiology and } \\
\text { cirrhosis severity }\end{array}$ \\
\hline Newcastle-Ottawa score & $\begin{array}{l}\text { Selection: } 4 \\
\text { Comparability: } 2 \\
\text { Outcome: } 3\end{array}$ & $\begin{array}{l}\text { Selection: } 3 \\
\text { Comparability: } 1 \\
\text { Outcome: } 3\end{array}$ & $\begin{array}{l}\text { Selection: } 3 \\
\text { Comparability: } 2 \\
\text { Outcome: } 3\end{array}$ \\
\hline
\end{tabular}

ICD; International classification of diseases; MELD, model for end-stage liver disease; N/A, not available; PPI, proton pump inhibitors

organism of community-acquired pneumonia in patients with cirrhosis compared with the general population [24].

The second possible mechanism is related to intestinal bacterial overgrowth and translocation. PPIs, as acid suppressors, are known to induce intestinal dysbiosis and subsequent development of small intestinal bacterial overgrowth [25-27]. The complication of small intestinal bacterial overgrowth is more problematic among patients with cirrhosis than in healthy individuals, as they tend to have some degree of immunodeficiency through several mechanisms, including loss of Kupffer in the hepatic reticuloendothelial system, imbalance of cytokines causing immune cell dysfunction, and decreased hepatic synthesis of complements and acute phase reactants $[4,11,28,29]$. In addition, a significant portion of patients with cirrhosis develop portal hypertension with portal-system shunting that would bypass the normal process of hepatic bacterial clearance [4]. All of these factors may predispose cirrhotic patients to a higher likelihood of intestinal bacterial translocation and bacteremia that would ultimately lead to organ-specific infection, including pneumonia.

The current study has some limitations that should be acknowledged. First, publication bias was present in this systematic review and meta-analysis, as evidenced by the asymmetric funnel plot and positive Egger's regression test. Second, more than half of the studies included were cross- 


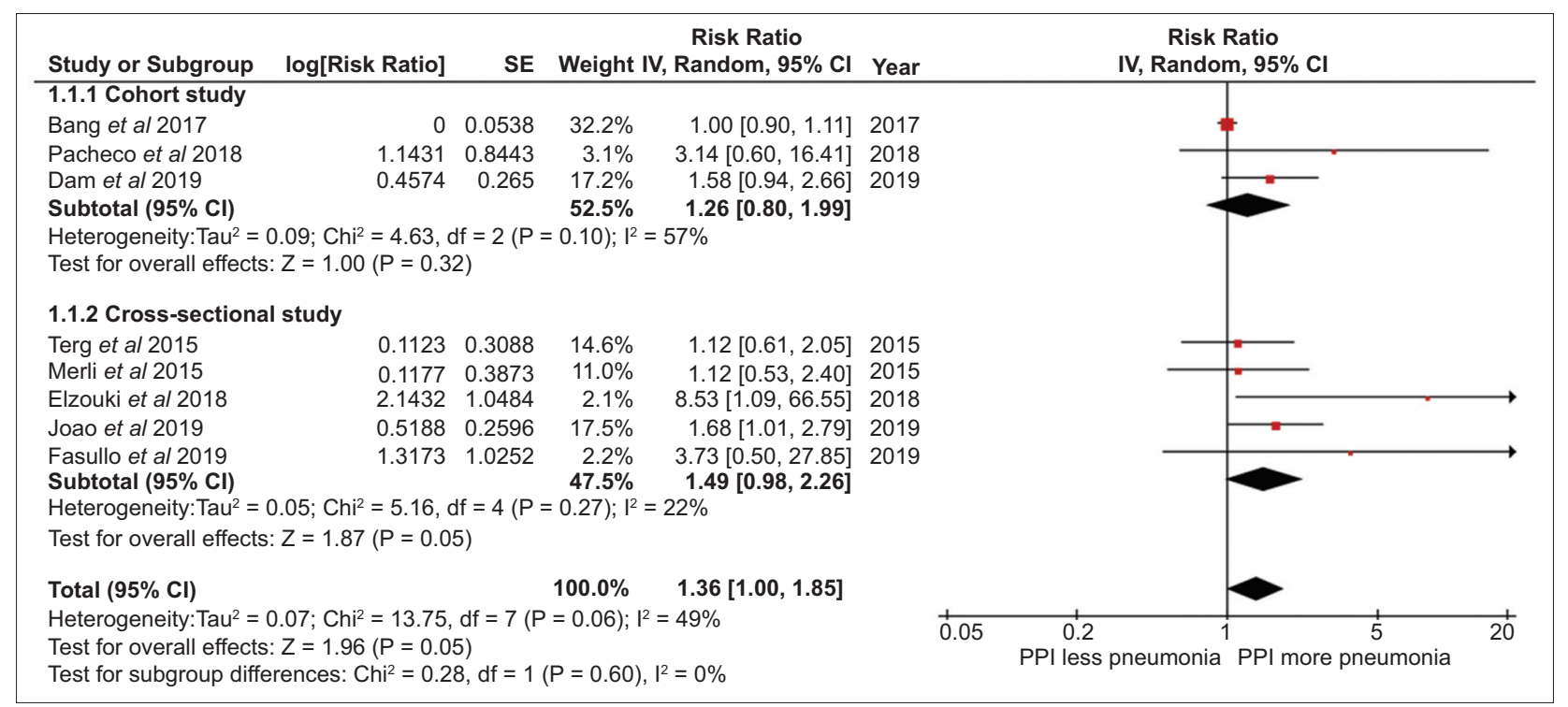

Figure 2 Forest plot of this meta-analysis

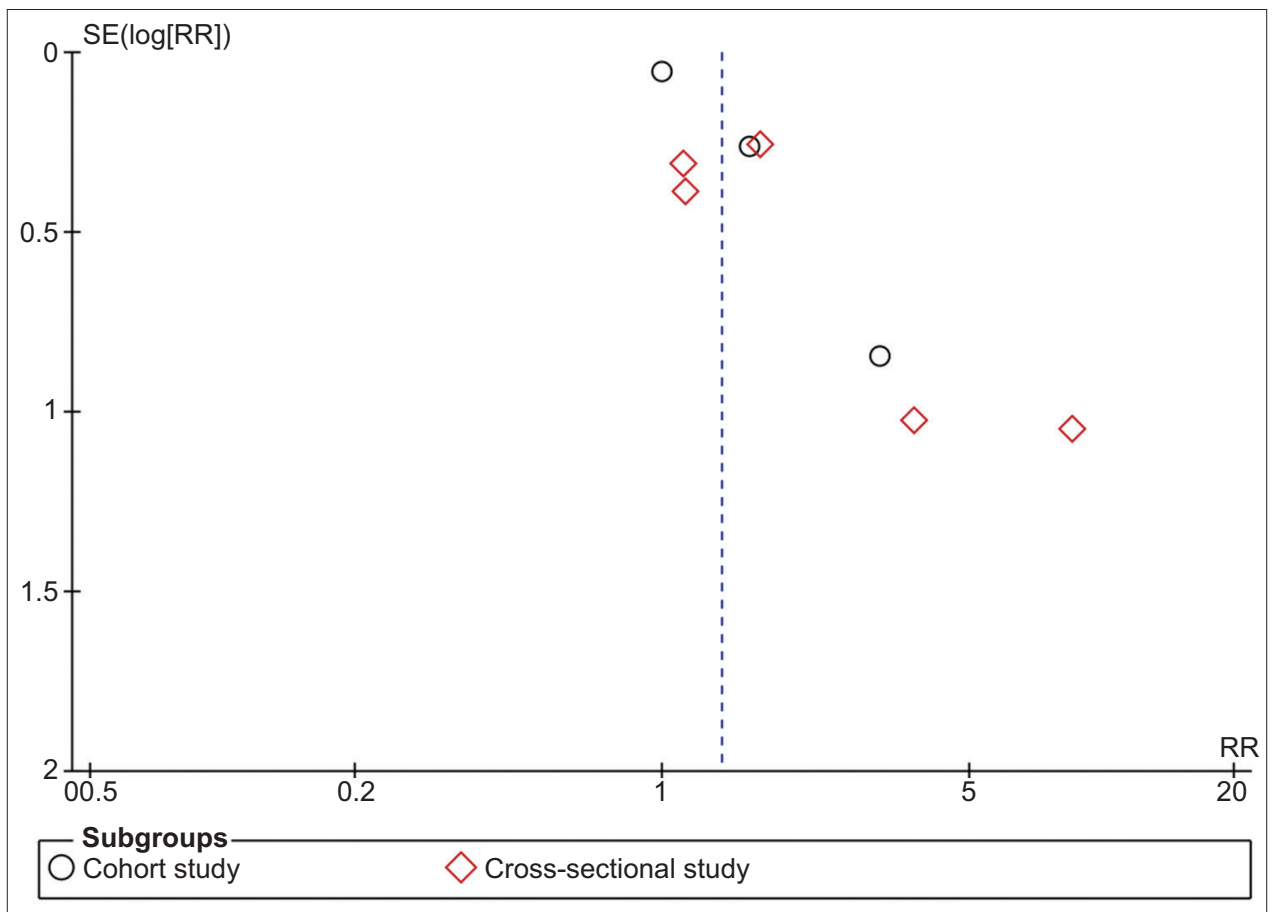

Figure 3 Funnel plot of this meta-analysis

sectional in nature. Therefore, the causality of the observed association cannot be reliably established. Third, the majority of studies included in this meta-analysis did not adjust their results for potential confounders. Therefore, the observed association could be a result of a confounding effect rather than a true association. Fourth, none of the included studies specifically aimed to investigate the relationship between PPI use and the occurrence of pneumonia. Their primary objective was to investigate the relationship between PPI use and the occurrence of either SBP or overall infection. Therefore, the number of patients with pneumonia was relatively small. Finally, the dosing of PPIs varied considerably across the included studies, especially among cross-sectional studies.

In conclusion, the present systematic review and metaanalysis demonstrated a significantly increased risk of pneumonia among cirrhotic patients with PPI use, although some limitations that may jeopardize the validity of the results were noted. 


\section{Summary Box}

\section{What is already known:}

- Proton pump inhibitors (PPIs) are commonly prescribed for cirrhotic patients

- However, over half of PPI regimens are prescribed without valid indications

- This increases the risk of several complications, such as hepatic encephalopathy, Clostridium difficile infection and spontaneous bacterial peritonitis

\section{What the new findings are:}

- The pooled analysis found that cirrhotic patients with a history of PPI use had a significantly higher risk of developing pneumonia than those without PPI use

- Based on the pooled analysis of 8 eligible studies, the risk was increased by 1.36 times

- Possible mechanisms included decreased gastric acidity and intestinal bacterial overgrowth

\section{References}

1. Asrani SK, Devarbhavi H, Eaton J, Kamath PS. Burden of liver diseases in the world. J Hepatol 2019;70:151-171.

2. Nusrat S, Khan MS, Fazili J, Madhoun MF. Cirrhosis and its complications: evidence based treatment. World J Gastroenterol 2014;20:5442-5460.

3. Bunchorntavakul C, Chavalitdhamrong D. Bacterial infections other than spontaneous bacterial peritonitis in cirrhosis. World $J$ Hepatol 2012;4:158-168.

4. Albillos A, Lario M, Álvarez-Mon M. Cirrhosis-associated immune dysfunction: Distinctive features and clinical relevance. J Hepatol 2014;61:1385-1396.

5. Chavez-Tapia NC, Tellez-Avila FI, Garcia-Leiva J, Valdovinos MA. Use and overuse of proton pump inhibitors in cirrhotic patients. Med Sci Monit 2008;14:CR468-CR472.

6. Zhu J, Yu H, Mancuso A, Qi X. Proton pump inhibitors in liver cirrhosis: a review of benefits and harms. AME Med J 2017;2:36.

7. Miozzo SAS, John JA, Appel-da-Silva MC, Dossin IA, Tovo CV, Mattos AA. Influence of proton pump inhibitors in the development of spontaneous bacterial peritonitis. World J Hepatol 2017;9:1278-1285.

8. Lo WK, Chan WW. Proton pump inhibitor use and the risk of small intestinal bacterial overgrowth: a meta-analysis. Clin Gastroenterol Hepatol 2013;11:483-490.

9. Koulaouzidis A, Bhat S, Karagiannidis A, Tan WC, Linaker BD. Spontaneous bacterial peritonitis. Postgrad Med J 2007;83:379-383.

10. Bang UC, Bendtsen F. The use of proton pump inhibitors is not associated with an increased risk of infections in a cohort of patients with alcoholic cirrhosis from Danish nationwide registers. Hepatology 2017;66(Suppl):286A.
11. Dam G, Vilstrup H, Andersen PK, Bossen L, Watson H, Jepsen P. Effect of proton pump inhibitors on the risk and prognosis of infections in patients with cirrhosis and ascites. Liver Int 2019;39:514-521.

12. Elzouki AN, Neffati N, Rasoul FA, Abdallah A, Othman M, Waness A. Increased risk of spontaneous bacterial peritonitis in cirrhotic patients using proton pump inhibitors. GE Port $J$ Gastroenterol 2019;26:83-89.

13. Fasullo M, Rau P, Liu DQ, et al. Proton pump inhibitors increase the severity of hepatic encephalopathy in cirrhotic patients. World J Hepatol 2019;11:522-530.

14. João M, Mendes J, Louro E, Simão A, Carvalho A. Proton pump inhibitors as a risk factor for hepatic encephalopathy and infections in cirrhotic patients: a clinical evidence. J Hepatol 2019;70:e653.

15. Lázaro-Pacheco IB, Servín-Caamaño AI, Pérez-Hernández JL, Rojas-Loureiro G, Servín-Abad L, Tijera FH. Proton pump inhibitors increase the overall risk of developing bacterial infections in patients with cirrhosis. Arq Gastroenterol 2018;55:28-32.

16. Merli M, Lucidi C, Di Gregorio V, et al. The chronic use of betablockers and proton pump inhibitors may affect the rate of bacterial infections in cirrhosis. Liver Int 2015;35:362-369.

17. Terg R, Casciato P, Garbe C, et al; Study Group of Cirrhosis Complications of the Argentine Association for the Study of Liver Disease. Proton pump inhibitor therapy does not increase the incidence of spontaneous bacterial peritonitis in cirrhosis: a multicenter prospective study. J Hepatol 2015;62:1056-1060.

18. Wells GA, Shea B, O'Connell D, et al. The Newcastle-Ottawa Scale (NOS) for assessing the quality of nonrandomised studies in metaanalyses. Available at: http://www.ohri.ca/programs/clinical_ epidemiology/oxford.asp [Accessed 30 March 2020].

19. DerSimonian R, Laird N. Meta-analysis in clinical trials. Control Clin Trials 1986;7:177-188.

20. Higgins JP, Thompson SG, Deeks JJ, Altman DG. Measuring inconsistency in meta-analyses. BMJ 2003;327:557-560.

21. Lambert AA, Lam JO, Paik JJ, Ugarte-Gil C, Drummond MB, Crowell TA. Risk of community-acquired pneumonia with outpatient proton-pump inhibitor therapy: a systematic review and meta-analysis. PloS One 2015;10:e128004.

22. Freedberg DE, Lebwohl B, Abrams JA. The impact of proton pump inhibitors on the human gastrointestinal microbiome. Clin Lab Med 2014;34:771-785.

23. du Moulin GC, Paterson DG, Hedley-Whyte J, Lisbon A. Aspiration of gastric bacteria in antacid-treated patients: a frequent cause of postoperative colonisation of the airway. Lancet 1982;1:242-245.

24. Viasus D, Garcia-Vidal C, Castellote J, et al. Community-acquired pneumonia in patients with liver cirrhosis: clinical features, outcomes, and usefulness of severity scores. Medicine (Baltimore) 2011:90:110-118.

25. Imhann F, Bonder MJ, Vich Vila A, et al. Proton pump inhibitors affect the gut microbiome. Gut 2016;65:740-748.

26. Revaiah PC, Kochhar R, Rana SV, et al. Risk of small intestinal bacterial overgrowth in patients receiving proton pump inhibitors versus proton pump inhibitors plus prokinetics. JGH Open 2018;2:47-53.

27. Bruno G, Zaccari P, Rocco G, et al. Proton pump inhibitors and dysbiosis: Current knowledge and aspects to be clarified. World J Gastroenterol 2019;25:2706-2719.

28. Garcia-Tsao G, Wiest R. Gut microflora in the pathogenesis of the complications of cirrhosis. Best Pract Res Clin Gastroenterol 2004; 18:353-372.

29. Tuchendler E, Tuchendler PK, Madej G. Immunodeficiency caused by cirrhosis. Clin Exp Hepatol 2018;4:158-164. 


\section{Supplementary Tables}

Supplementary Table 1

Search strategy

EMBASE

1. 'proton pump inhibitor'/exp OR 'proton pump inhibitor'
2. 'proton pump antagonist'
3. 'lansoprazole'/exp OR 'lansoprazole'
4. 'dexlansoprazole'/exp OR 'dexlansoprazole'
5. 'omeprazole'/exp OR 'omeprazole'
6. 'esomeprazole'/exp OR 'esomeprazole'
7. 'pantoprazole'/exp OR 'pantoprazole'
8. 'rabeprazole'/exp OR 'rabeprazole'
9. 'dexrabeprazole'/exp OR dexrabeprazole
10. \#1 OR \#2 OR \#3 OR \#4 OR \#5 OR \#6 OR \#7 OR \#8 OR \#9
11. 'liver cirrhosis'/exp OR 'liver cirrhosis'
12. 'cirrhosis'/exp OR cirrhosis
13. cirrhotic
14. 'chronic liver disease'/exp OR 'chronic liver disease'
15. 'chronic hepatitis'/exp OR 'chronic hepatitis'
16. \#11 OR \#12 OR \#13 OR \#14 OR \#15
17. \#10 AND \#16

MEDLINE

1. proton pump inhibitors.mp. or exp Proton Pump Inhibitors/

2. proton pump antagonist.mp.

3. lansoprazole.mp. or exp Lansoprazole/

4. dexlansoprazole.mp. or exp Dexlansoprazole/

5. omeprazole.mp. or exp Omeprazole/

6. esomeprazole.mp. or exp Esomeprazole/

7. pantoprazole.mp. or exp Pantoprazole/

8. rabeprazole.mp. or exp Rabeprazole/

9. dexrabeprazole.mp.

10. 1 or 2 or 3 or 4 or 5 or 6 or 7 or 8 or 9

11. cirrhosis.mp.

12. exp Liver Cirrhosis/ or cirrhotic.mp.

13. chronic liver disease.mp.

14. chronic hepatitis.mp. or exp Hepatitis, Chronic/

15. 11 or 12 or 13 or 14

16. 10 and 15 
Supplementary Table 2

\begin{tabular}{llll}
\hline Section/topic & Cheacklist item & Reported on page \\
\hline TITLE & 1 & Identify the report as a systematic review, meta-analysis, or both. & 1 \\
\hline Title & & & $\begin{array}{l}\text { Provide a structured summary including, as applicable: background; objectives; data } \\
\text { sources; study eligibility criteria, participants, and interventions; study appraisal and } \\
\text { synthesis methods; results; limitations; conclusions and implications of key findings; } \\
\text { systematic review registration number. }\end{array}$ \\
\hline ABSTRACT & & & $\begin{array}{l}\text { Describe the rationale for the review in the context of what is already known. } \\
\text { Structured summary }\end{array}$ \\
\hline INTRODUCTION & 4 & $\begin{array}{l}\text { Provide an explicit statement of questions being addressed with reference to participants, } \\
\text { interventions, comparisons, outcomes, and study design (PICOS). }\end{array}$ & 4 \\
\hline Rationale & & \\
\hline Objectives & &
\end{tabular}

\begin{tabular}{|c|c|c|c|}
\hline $\begin{array}{l}\text { Protocol and } \\
\text { registration }\end{array}$ & 5 & $\begin{array}{l}\text { Indicate if a review protocol exists, if and where it can be accessed (e.g., Web address), } \\
\text { and, if available, provide registration information including registration number. }\end{array}$ & $\begin{array}{l}4 \text { and Supplementary } \\
\text { Table } 1\end{array}$ \\
\hline Eligibility criteria & 6 & $\begin{array}{l}\text { Specify study characteristics (e.g., PICOS, length of follow up) and report characteristics (e.g., } \\
\text { years considered, language, publication status) used as criteria for eligibility, giving rationale. }\end{array}$ & 5 \\
\hline Information sources & 7 & $\begin{array}{l}\text { Specify study characteristics (e.g., PICOS, length of follow up) and report characteristics (e.g., } \\
\text { years considered, language, publication status) used as criteria for eligibility, giving rationale. }\end{array}$ & 5 \\
\hline Search & 8 & $\begin{array}{l}\text { Present full electronic search strategy for at least one database, including any limits used, } \\
\text { such that it could be repeated. }\end{array}$ & $\begin{array}{l}5 \text { and Supplementary } \\
\text { Table } 1\end{array}$ \\
\hline Study selection & 9 & $\begin{array}{l}\text { State the process for selecting studies (i.e., screening, eligibility, included in systematic } \\
\text { review, and, if applicable, included in the meta-analysis). }\end{array}$ & $5-6$ \\
\hline $\begin{array}{l}\text { Data collection } \\
\text { process }\end{array}$ & 10 & $\begin{array}{l}\text { Describe method of data extraction from reports (e.g., piloted forms, independently, in } \\
\text { duplicate) and any processes for obtaining and confirming data from investigators. }\end{array}$ & 6 \\
\hline Data items & 11 & $\begin{array}{l}\text { List and define all variables for which data were sought (e.g., PICOS, funding sources) } \\
\text { and any assumptions and simplifications made. }\end{array}$ & 6 \\
\hline $\begin{array}{l}\text { Risk of bias in } \\
\text { individual studies }\end{array}$ & 12 & $\begin{array}{l}\text { Describe methods used for assessing risk of bias of individual studies (including } \\
\text { specification of whether this was done at the study or outcome level), and how this } \\
\text { information is to be used in any data synthesis. }\end{array}$ & Table 1and 2 \\
\hline Summary measures & 13 & State the principal summary measures (e.g., risk ratio, difference in means). & 8 \\
\hline Synthesis of results & 14 & $\begin{array}{l}\text { Describe the methods of handling data and combining results of studies, if done, } \\
\text { including measures of consistency (e.g., I2) for each meta-analysis }\end{array}$ & 8 \\
\hline $\begin{array}{l}\text { Risk of bias across } \\
\text { studies }\end{array}$ & 15 & $\begin{array}{l}\text { Specify any assessment of risk of bias that may affect the cumulative evidence (e.g., } \\
\text { publication bias, selective reporting within studies). }\end{array}$ & Figure 3 \\
\hline Additional analyses & 16 & $\begin{array}{l}\text { Describe methods of additional analyses (e.g., sensitivity or subgroup analyses, meta- } \\
\text { regression), if done, indicating which were pre-specified. }\end{array}$ & 9 \\
\hline
\end{tabular}

RESULTS

\begin{tabular}{lclll}
\hline Study selection & 17 & $\begin{array}{l}\text { Give numbers of studies screened, assessed for eligibility, and included in the review, } \\
\text { with reasons for exclusions at each stage, ideally with a flow diagram. }\end{array}$ & 7-8 \\
\hline $\begin{array}{l}\text { Study characteristics } \\
\text { Risk of bias within }\end{array}$ & 19 & $\begin{array}{l}\text { For each study, present characteristics for which data were extracted (e.g., study size, } \\
\text { PICOS, follow-up period) and provide the citations. }\end{array}$ & $\begin{array}{l}\text { Present data on risk of bias of each study and, if available, any outcome level assessment } \\
\text { (see item 12). }\end{array}$ & Table 1 \\
$\begin{array}{l}\text { studies } \\
\begin{array}{l}\text { Results of individual } \\
\text { studies }\end{array}\end{array}$ & 20 & $\begin{array}{l}\text { For all outcomes considered (benefits or harms), present, for each study: (a) simple } \\
\text { summary data for each intervention group (b) effect estimates and confidence intervals, } \\
\text { ideally with a forest plot. }\end{array}$ & Figure 2 \\
\hline
\end{tabular}




\begin{tabular}{|c|c|c|c|}
\hline Synthesis of results & 21 & $\begin{array}{l}\text { Present results of each meta-analysis done, including confidence intervals and measures } \\
\text { of consistency. }\end{array}$ & 8 \\
\hline $\begin{array}{l}\text { Risk of bias across } \\
\text { studies }\end{array}$ & 22 & Present results of any assessment of risk of bias across studies (see Item 15). & Figure 3 \\
\hline Additional analysis & 23 & $\begin{array}{l}\text { Give results of additional analyses, if done (e.g., sensitivity or subgroup analyses, meta- } \\
\text { regression [see Item 16]). }\end{array}$ & 9 \\
\hline \multicolumn{4}{|l|}{ DISCUSSION } \\
\hline $\begin{array}{l}\text { Summary of } \\
\text { evidence }\end{array}$ & 24 & $\begin{array}{l}\text { Summarize the main findings including the strength of evidence for each main outcome; } \\
\text { consider their relevance to key groups (e.g., healthcare providers, users, and policy } \\
\text { makers). }\end{array}$ & 9 \\
\hline Limitations & 25 & $\begin{array}{l}\text { Discuss limitations at study and outcome level (e.g., risk of bias), and at review-level } \\
\text { (e.g., incomplete retrieval of identified research, reporting bias). }\end{array}$ & 10 \\
\hline Conclusions & 26 & $\begin{array}{l}\text { Provide a general interpretation of the results in the context of other evidence, and } \\
\text { implications for future research. }\end{array}$ & 10 \\
\hline
\end{tabular}

FUNDING

\begin{tabular}{llll}
\hline Funding & 27 & $\begin{array}{l}\text { Describe sources of funding for the systematic review and other support (e.g., supply of } \\
\text { data); role of funders for the systematic review. }\end{array}$ & 1 \\
\hline
\end{tabular}

From: Moher D, Liberati A, Tetzlaff J, Altman DG, The PRISMA Group (2009). Preferred Reporting Items for Systematic Reviews and Meta-Analyses: The PRISMA Statement. PLoS Med 6: e1000097.

doi:10.1371/journal.pmed1000097

For more information, visit: www.prisma-statement.org. 